\title{
DERIVATIVES USAGE IN RISK MANAGEMENT BY TURKISH NON-FINANCIAL FIRMS AND BANKS: A COMPARATIVE STUDY
}

\author{
Yakup Selvi ${ }^{1}$ \\ Aslı Türel ${ }^{2}$
}

\begin{abstract}
The purpose of this study to compare the previous research about how the nonfinancial companies listed in the Istanbul Stock Exchange (ISE) and deposit banks in Turkey have disclosed information regarding the usage of derivatives, and the accounting treatment of these derivatives. The results of these studies indicate that banks and the non-financial companies listed in the ISE-100 Indices, which represent $86 \%$ of the market capitalization, use derivatives mainly for hedging purposes. However, the evidence that they usually prefer reporting their gains/losses arising from these transactions as "held for trading" instead of applying "hedge accounting", since they could not meet the compulsory criterions described in the IAS 39.
\end{abstract}

Key Words: Derivative Instruments, IAS 39, IFRS 7, Hedge Accounting,

JEL codes: G32, M41

\section{Introduction}

Over the last decade the business environment has become more and more global, which has led to an increasing level of competition but also enabled entities to gain access to new customers and additional resource markets. With a growing diversity of international business operations an increase in risks naturally comes along, especially with risks related to financial issues such as fluctuating currencies, commodity prices and interest rates. When companies face those kinds of risks, a common way to deal with such issue is the usage of hedge instruments. Hedging can basically be described as an attempt to reduce the risk of an underlying transaction by concluding an adverse transaction in order to offset the risks (Hausin M.et al., 2008). New financial instruments such as derivatives have been intensively used to hedge these risks. Derivatives are kinds of financial instruments whose changes in market value are depending on changes in underlying variables (asset and/or liabilities). Common examples of underlying variables are interest rates, exchange rates, stock prices, stock-market indices, or prices of commodities. Besides hedging risks, derivatives can be used for trading (speculative) purposes. Though the primary users of derivatives are financial institutions such as banks, insurance companies, and investment managers, the usage of derivatives by non-financial firms is considerable (Bartram Söhnke M. et al., 2006, p.4).

To improve the transparency with respect to derivative instruments and to avoid large derivative losses from speculation, the Standard Setters have required firms to disclose more and more of their derivatives information (Nan L., 2007). Globally, International Accounting Standard Board (IASB) has been issuing standards about accounting for derivatives.

In this study, we compare the previous research (Selvi Y. et al., 2007, Türel A., 2008) about the usage of derivatives and the accounting treatment of these derivatives in the annual reports by

\footnotetext{
1 Istanbul University, School of Business, Avcilar Kampusu, Isletme Fakultesi, Avcilar /Istanbul, email: selviyak@istanbul.edu.tr

${ }^{2}$ Istanbul University, School of Business, email: gunduzay@ istanbul.edu.tr
} 
the non-financial companies listed in the Istanbul Stock Exchange (ISE) and deposit banks operate in the Turkish Banking Sector (TBS).

\section{Prior Research}

Several studies have investigated derivatives usage for risk management purposes in the United States (US). The often cited Wharton Surveys (Bodnar et al., 1998) provide detailed descriptions of derivatives usage among US non-financial firms. A number of similar studies have examined derivatives usage in several countries. Studies include: New Zealand (Berkman et al., 1997), Sweden (Alkeback and Hagelin, 1999), Germany (Bhamornsiri and Schroeder, 2004), Belgium (De Ceuster et al., 2000), UK (Joseph, 2000, Mallin et al., 2001). Purpose of this paper is to add to the countries in this list by investigating derivatives use among firms in Turkey.

Bodnar et al. (1998) found that derivatives use is not widespread, with less than half of the population of firms using financial derivatives of any kind. While the intensity of derivatives use appears to be increasing among the firms using derivatives, no compelling evidence iuggests that the total percentage of firms using derivatives has changed dramatically over the past four years. Foreign-currency derivatives are the most commonly used, followed by interest-rate, commodity, and equity derivatives, respectively.

Alkeback and Hagelin (1999) studied derivatives usage in Sweden. Their findings show that the lack of knowledge about derivatives within the firm is the main concern of Swedish firms. De Ceuster et al. (2000) found that Belgian firms focus their hedging strategies more on reducing earnings volatility than on reducing cash flow volatility.

Berkman et al. (1997) studied derivatives usage in New Zealand. They found that, in comparison with US firms, New Zealand firms hedge more financial risk across all size categories. Mallin et al. (2001) sent a questionnaire to the financial directors of 800 UK non-financial listed firms. They found that the primary objective cited by the firms for using derivatives is to manage fluctuations in accounting earnings, a view that is inconsistent with theoretical arguments on risk management.

Bhamornsiri and Schroeder (2004) examined the annual reports of the 30 companies that comprise the Dow Jones Industrial Average to determine the extent to which these companies complied with the provisions of SFAS No. 133. According to their findings, a large number of the sample companies reported that the effect of their hedging activities was immaterial. The study also found that the information disclosed about the derivatives held by the sample of companies was scattered throughout their annual reports, hard to understand, difficult to follow and lacked uniformity.

Zhang (2009) found that, volatility of cash flow and risk exposures related to interest rate, foreign exchange rate, and commodity price decrease significantly for Ineffective Hedger/Speculator firms but not for Effective Hedger firms, suggesting that Ineffective Hedger/Speculator firms engaged in more prudent risk management activities after the adoption of SFAS No133.

Joseph (2000) studied the relationship between the use of hedging techniques and the characteristics of UK multinational enterprises (MNEs). All the firms in his sample hedge foreign exchange (FX) exposure. The results indicate that UK firms focus on a very narrow set of hedging techniques. They make much greater use of derivatives than internal hedging techniques. Clark (2009) found that there is no direct link between risk management and hedge accounting. In particular, hedge accounting is not applied to all economic hedge relationships.

Bartram et al. (2009) found strong evidence that the use of financial derivatives reduces both total risk and systematic risk. The effect of derivative use on firm value is positive but more sensitive to endogeneity and omitted variable concerns. However, using derivatives is associated with significantly higher value, abnormal returns, and larger profits during the economic downturn in 2001-2002, suggesting firms are hedging downside risk. 
Bartram et al. (2006) found that derivative use is significantly related to important financial characteristics such as leverage, debt maturity, and holdings of liquid assets, dividend policy, and operational hedges. Their results suggest that subsequent research should examine more complex models of firm risk that can better explain the role of derivatives in overall financial policy and potentially resolve some of the apparent conflicts with theory that we document.

\section{The Regulatory Framework for Derivatives}

Some problems exist related to the accounting and reporting practices for derivative instruments and hedging activities. Such as;

a)Recognition problem. How to record them?

b) Measurement problem.

a. Do we measure them at the reporting date?

b.If yes, which value will be used for measurement?

c. And, how to record the gain or losses that is the result of the measurement?

c)Disclosure problem. How to disclose them in financial statements?

To overcome these accounting problems, standard setters have been issuing some standards locally or globally. Globally the IASB, issued IAS 32 (Financial Instruments: Disclosure and Presentation) in June 1995 and IAS 39 (Financial Instruments: Realization and Measurement) in December 1998. After considerable debates about problems of these standards, IASB revised these two standards. Lastly, International Financial Reporting Standard (IFRS) 7 "Financial Instruments: Disclosures" was published in August 2005.

The objective of IAS 32 is to enhance financial statement users' understanding of the significance of financial instruments to an entity's financial position, performance, and cash flows. ${ }^{3}$ The objective of IAS 39 is to establish principles for recognizing, and measuring financial instruments in the financial statements of business enterprises (Deloitte Touche Tohmatsu (eds.), 2002, p.76). The objective of IFRS 7 is to require entities to provide disclosures in their financial statements that enable users to evaluate ${ }^{4}$ :

a) the significance of financial instruments for the entity's financial position and performance;

b) the nature and extent of risks arising from financial instruments to which the entity is exposed at the reporting date, and how the entity manages them.

IASs and IFRSs have become effective in the member countries of European Union since January $1,2005$.

In national dimension, Banking Regulation and Supervision Agency of Turkey, Capital Market Board of Turkey and Turkish Accounting Standards Board (TSAB) published accounting regulations about derivatives and hedge accounting. The TASB translated the complete set of the IFRS's and IAS's and published the translation by declaring them as the Turkish Financial Reporting Standards (TFRS's) in April 2006. This was the major move from the Turkish government towards a complete adoption to the IFRS's in listed and unlisted Turkish companies. TFRS's are fully compatible with IFRS's. By this implementation accounting practices become compatible with the regulations of the EU and IOSCO (International Organization of Securities Commission).

In Turkey, the Capital Market Board of Turkey (CMB) is the regulatory and supervisory authority in charge of the securities markets. CMB issued a broad set of financial reporting standards(Capital Markets Board, 2003) that are fully compatible with all International Financial

\footnotetext{
${ }^{3}$ http://www.iasplus.com/standard/ias32.htm, July 07, 2006.

${ }^{4}$ http://www.kpmg.lu/Download/IFRS\%20Briefing/IFRSBriefing\%20Sheet\%20-\%20Issue\%2034.september2005.pdf, July 20, 2006.
} 
Reporting Standards. These standards become effective for the financial statement of listed companies in the ISE covering periods beginning on or after January 1, 2005. The Turkish Capital Markets Board published the latest communiqué about accounting on April 9, 2008 (Capital Markets Board, 2008). According to the latest communiqué, companies registered at the Turkish Capital Markets Board have to implement Turkish Financial Reporting Standards as adopted by the EU and disclose this fact in their published financial statements.

The Turkish Banking Regulation and Supervising Agency issued "regulation on accounting principles" on June 22, 2002. The purpose of this regulation was to determine the basis, principles and procedures regarding to provide transparency and uniformity in accounting and record order of banks. With publishing the new document, the agency accepted the implementation of the Turkish Financial Reporting Standard's starting by January 1, 2007.

However, the most effective standard setter in Turkey, the Ministry of Finance had not yet eliminated its regulation on accounting standards (Aysan M.A., 2008, pp.13). The Ministry of Finance's Uniform Accounting Standards and the Related Plan of Accounts are still operative until now. All tax-paying accounting units in Turkey had to prepare their income and corporation tax returns in accordance with the Ministry of Finance standards and Chart of Accounts published on 26 December 1992.

\section{Turkish Experience about Derivatives}

Two empirical studies (Selvi Y. et al., 2007; Türel A., 2008) have been made about the derivatives disclosed in financial statements in Turkey. The aims of these studies are to find out the use of derivatives and the accounting treatment of their transactions by the non-financial companies listed in the Istanbul Stock Exchange 100 Index (ISE-100) (ISE-100 listed companies represent $86 \%$ of market capitalization), and the deposit banks that operate in Turkish Banking sector.

For this purpose, December 31, 2006 dated consolidated financial statements and disclosures related to these financial statements of 79 non-financial companies and 33 Deposit Banks are examined. From 33 Deposit Banks 21 of them are listed in ISE-100 Index.

Companies that are listed in the Istanbul Stock Exchange-100

Table no.1

\begin{tabular}{|c|l|l|r|}
\hline & $\begin{array}{l}\text { Financial } \\
\text { Companies }\end{array}$ & $\begin{array}{l}\text { Non-Financial } \\
\text { Companies }\end{array}$ & Total \\
\hline ISE-100 & 21 & 79 & 100 \\
\hline
\end{tabular}

Table no. 1 and Table no. 2 reports the numbers of companies that are listed in the Istanbul Stock Exchange-100 and the number of banks operating in Turkey. Although in Turkey 50 banks are operating in 2006, our study only covers the deposit banks (33 banks).

Banks Operating in Turkey Based on Operation

Table no. 2

\begin{tabular}{|l|l|l|l|}
\hline & $\begin{array}{l}\text { Deposit } \\
\text { Banks }\end{array}$ & $\begin{array}{l}\text { Participation, } \\
\text { Development } \\
\text { \& Investment }\end{array}$ & Total \\
\hline Number of Banks & 33 & 17 & 50 \\
\hline
\end{tabular}

Table no. 3 shows the percentage of using derivatives of non financial companies in ISE-100 Index and deposit banks. According to the Table-3, 35\% of the non financial companies in ISE-100 Index and $85 \%$ of deposit banks in Turkey are using derivative instruments. This finding supports that derivatives are widely used by banks in Turkey. 
Usage of Derivative Instruments

\begin{tabular}{|l|r|r|r|}
\hline & \multicolumn{1}{|c|}{ Yes } & \multicolumn{1}{|c|}{ No } & Total \\
\hline ISE-100 & $\mathbf{2 8}$ & $\mathbf{5 1}$ & $\mathbf{7 9}$ \\
\hline$\%$ in ISE-100 & $35 \%$ & $65 \%$ & $100 \%$ \\
\hline DEPOSIT BANKS & $\mathbf{2 8}$ & $\mathbf{5}$ & $\mathbf{3 3}$ \\
\hline$\%$ in 33 DB & $85 \%$ & $15 \%$ & $100 \%$ \\
\hline
\end{tabular}

Table no. 3

Table no. 4 breaks down derivatives usage by type of instruments. Forwards (64\%) and swaps $(39 \%)$ are the most commonly used instruments, while options $(18 \%)$ and futures $(11 \%)$ are much less common by non financial companies in ISE-100 Index. Also we observed that forwards $(89 \%)$ and, swaps $(100 \%)$ are both extensively used by banks in Turkey. On the other hand, we found that deposit banks use futures and options more extensively than non financial companies in ISE-100 Index.

Table no. 4

Types of Derivative Instruments Used

\begin{tabular}{|l|r|r|r|r|r|l|}
\hline & Forward & Futures & Option & Swap & Other & $\begin{array}{l}\text { Not } \\
\text { Mentioned }\end{array}$ \\
\hline ISE-100 & $\mathbf{1 8}$ & $\mathbf{3}$ & $\mathbf{5}$ & $\mathbf{1 1}$ & $\mathbf{0}$ & $\mathbf{1}$ \\
\hline \% in 28 Companies & $64 \%$ & $11 \%$ & $18 \%$ & $39 \%$ & 0 & $4 \%$ \\
\hline \% in ISE-100 of 79 & $23 \%$ & $4 \%$ & $6 \%$ & $14 \%$ & 0 & $1 \%$ \\
\hline Deposit Banks & $\mathbf{2 5}$ & $\mathbf{1 1}$ & $\mathbf{1 4}$ & $\mathbf{2 8}$ & $\mathbf{6}$ & $\mathbf{0}$ \\
\hline$\%$ in 28 DB & $89 \%$ & $39 \%$ & $50 \%$ & $100 \%$ & $21 \%$ & 0 \\
\hline \% in 33 DB & $76 \%$ & $33 \%$ & $42 \%$ & $85 \%$ & $18 \%$ & 0 \\
\hline
\end{tabular}

Derivatives users are classified by the underlying asset in Table-5. Most common is the use of currency derivatives $(82 \%)$ by non financial companies in ISE-100 Index, (100\%) by deposit bank, followed closely by interest rate derivatives (64\%) by deposit banks and (25\%) by non financial companies in ISE-100 Index. Only one deposit bank employs derivatives in order to stock index derivatives.

Table no. 5

\section{Used Derivative Instruments that are based on}

\begin{tabular}{|l|r|r|r|r|}
\hline & Currency & Interest & $\begin{array}{l}\text { Commodity / } \\
\text { Price }\end{array}$ & $\begin{array}{l}\text { Stock } \\
\text { Index }\end{array}$ \\
\hline ISE-100 & $\mathbf{2 3}$ & $\mathbf{7}$ & $\mathbf{6}$ & $\mathbf{0}$ \\
\hline \% in 28 Companies & $82 \%$ & $25 \%$ & $21 \%$ & - \\
\hline \% in ISE-100 of 79 & $29 \%$ & $9 \%$ & $8 \%$ & - \\
\hline Deposit Banks & $\mathbf{2 8}$ & $\mathbf{1 8}$ & $\mathbf{0}$ & $\mathbf{1}$ \\
\hline \% in 28 DB & $100 \%$ & $64 \%$ & 0 & $4 \%$ \\
\hline$\%$ in 33 DB & $85 \%$ & $55 \%$ & 0 & $3 \%$ \\
\hline
\end{tabular}

Table no. 6 reveals the objectives of the derivative usage by non financial companies in ISE100 Index and banks in Turkey. We observed that $82 \%$ of the non financial companies in ISE-100 Index and $86 \%$ of the banks in Turkey use derivatives for hedging purposes. On the other hand, $7 \%$ of the non financial companies in ISE-100 Index and $46 \%$ of the banks use derivatives also for speculative purposes. 
Table no. 6

The Purpose of Involving to Derivative Instruments

\begin{tabular}{|l|r|r|r|}
\hline & Hedge Purpose & Speculative Purpose & Not Mentioned \\
\hline ISE-100 & $\mathbf{2 3}$ & $\mathbf{2}$ & $\mathbf{5}$ \\
\hline \% in 28 Companies & $82 \%$ & $7 \%$ & $18 \%$ \\
\hline \% in ISE-100 of 79 & $29 \%$ & $3 \%$ & $6 \%$ \\
\hline Deposit Banks & $\mathbf{2 4}$ & $\mathbf{1 3}$ & $\mathbf{2}$ \\
\hline \% in 28 DB & $86 \%$ & $46 \%$ & $7 \%$ \\
\hline \% in 33 DB & $73 \%$ & $39 \%$ & $21 \%$ \\
\hline
\end{tabular}

Table no.7 reveals the preference of non financial companies in ISE-100 Index and banks in Turkey recording derivatives according to hedge accounting which is permitted by the IAS 39 . Also, Table-7 reveals that only $39 \%$ of the non financial companies in ISE-100 Index and $17 \%$ of the banks in Turkey prefer recording their hedge purpose derivatives according to hedge accounting. We observed that $48 \%$ of the non financial companies in ISE-100 Index and $83 \%$ of the banks in Turkey prefer recording their hedge purpose derivatives according to held for trading.

Table no.7

Did They Use the Hedge Accounting?

\begin{tabular}{|l|r|r|r|r|}
\hline & Yes & No & $\begin{array}{r}\text { Not } \\
\text { Mentioned }\end{array}$ & $\begin{array}{r}\text { Tot } \\
\text { al }\end{array}$ \\
\hline ISE-100 & $\mathbf{9}$ & $\mathbf{1 1}$ & $\mathbf{3}$ & $\mathbf{2 3}$ \\
\hline \% Companies of 23 & $39 \%$ & $48 \%$ & $13 \%$ & $100 \%$ \\
\hline \% in ISE-100 of 79 & $11 \%$ & $14 \%$ & $4 \%$ & - \\
\hline Deposit Banks & $\mathbf{4}$ & $\mathbf{2 0}$ & $\mathbf{0}$ & $\mathbf{2 4}$ \\
\hline \% in 24 DB & $17 \%$ & $83 \%$ & 0 & $100 \%$ \\
\hline$\%$ in 33 DB & $12 \%$ & $61 \%$ & 0 & - \\
\hline
\end{tabular}

According to Table no. 8, six of the eleven non-financial companies and eleven of the twenty deposit banks that not reported the hedging transaction according to "hedge accounting" policies disclosed the reason of "Not Using Hedge Accounting". In their footnotes they gave following explanation: "Even though certain derivative transactions, while providing effective economic hedges under the banks' risk management position, do not qualify for hedge accounting under the specific rules in Accounting Application Regulation and therefore, they are treated as derivatives held for trading."

Table no. 8

Did They Disclose Why Hedge Accounting is not used?

\begin{tabular}{|l|r|r|r|}
\hline & Yes & No & \multicolumn{1}{|c|}{ Total } \\
\hline ISE-100 & $\mathbf{6}$ & $\mathbf{5}$ & $\mathbf{1 1}$ \\
\hline \% Companies of 11 & $55 \%$ & $45 \%$ & $100 \%$ \\
\hline Deposit Banks & $\mathbf{1 1}$ & $\mathbf{9}$ & $\mathbf{2 0}$ \\
\hline$\%$ in 20 DB & $55 \%$ & $45 \%$ & $100 \%$ \\
\hline
\end{tabular}

Table no. 9 provides the hedge relationships of non financial companies in ISE-100 Index and banks who report according to hedge accounting. The five of the non-financial companies and three of the deposit banks which reported according to hedge accounting policies disclosed that they had been a party to a derivative contract in order to "fair value hedge". The four non-financial companies and one deposit bank which reported according to hedge accounting policies disclosed 
that they had been a party to a derivative contract in order to "cash flow hedge". None of them which reported according to hedge accounting policies disclosed that they had been a party to a derivative contract in order to "Hedge of Net Investment in a Foreign Operation".

Table no.9

Types of Hedge that Used

\begin{tabular}{|c|c|c|c|c|}
\hline & $\begin{array}{l}\text { Fair Value } \\
\text { Hedge }\end{array}$ & $\begin{array}{l}\text { Cash Flow } \\
\text { Hedge }\end{array}$ & $\begin{array}{l}\text { Hedge of Net Investment in a } \\
\text { Foreign Operation }\end{array}$ & Total \\
\hline ISE-100 & 5 & 4 & $\mathbf{0}$ & 9 \\
\hline$\%$ of Companies 9 & $56 \%$ & $44 \%$ & - & $100 \%$ \\
\hline$\%$ in ISE-100 of 79 & $6 \%$ & $5 \%$ & - & - \\
\hline Deposit Banks & 3 & 1 & $\mathbf{0}$ & 4 \\
\hline$\%$ in $4 \mathrm{DB}$ & $75 \%$ & $25 \%$ & - & $100 \%$ \\
\hline$\%$ in $33 \mathrm{DB}$ & $9 \%$ & $3 \%$ & - & $12 \%$ \\
\hline
\end{tabular}

\section{Conclusion and Empirical Findings}

In recent years, the corporate use of derivative instruments such as forwards, futures, swaps and options has been subject to rapid growth, both in terms of the extent of use and the complexity of the instruments employed. An effective financial presentation of the certain risks is therefore vital fort the users', especially for the investors' understanding of financial reports for their decision-making processes. This is of special importance when it comes to hedge accounting and an understanding of the companies' risk management policies, and how hedging affects the entities' financial performances and risk situations. Warren Buffett, former Chairman of Berkshire Hathaway, said in his 2002 Chairman's letter that “... derivatives are financial weapons of mass destruction, carrying dangers that, while now latent, are potentially lethal". To improve the transparency with respect to derivative instruments and to avoid large derivative losses from speculation, the Standard Setters have required firms to disclose more and more of their derivatives information (Nan L., 2007).

This study compares two previous researches about the use of derivatives, types of derivatives used, derivative use across risk classes, objectives for derivatives used, and reporting of derivatives according to hedging relationships for Istanbul Stock Exchange-100 companies and the deposit banks in Turkey. 35\% of the non financial companies in ISE-100 Index and 85\% of the deposit banks use derivatives. This finding supports that derivatives are widely used by banks in Turkey. In nature of forwards and swaps one part of the contract should be bank. Therefore, in these type of contracts both part may be banks but rarely non financial companies. According to our results all of the deposit banks use swaps and $89 \%$ uses forward. On the other hand, a big majority $(64 \%)$ of non financial companies in ISE-100 Index prefer using forwards. Futures are traded in organized market. Since futures market in Turkey is very new and not effective, the level of futures usage is low non financial companies in ISE-100 Index and bank. According to our results, banks use the futures relatively higher than non financial companies in ISE-100 Index, 39\% and 11\% respectively, because of their ability of trading in international organized markets.

The usage of derivatives that based on commodity/price is not common for banks because of their main operating targets. On the other hand the usage of commodity/price derivatives is expected for non financial companies in nature. Our next finding indicates that both non financial companies in ISE-100 Index and deposit banks use derivatives primarily to manage foreign exchange risk followed by an interest rate risk.

Derivative markets need speculators to exist. Banks can play this role easily than non financial companies especially in the countries that the market is developing. Since Turkey's derivative market is developing, $46 \%$ of the deposit banks use derivatives for trading purposes, whereas $7 \%$ of the non financial companies in ISE-100 Index use derivatives for trading purposes. 
Although banks and non financial companies prefer to use derivatives for hedging we noticed that only a small portion of non financial companies in ISE-100 Index (39\%) and deposit banks (17\%) prefer to use hedge accounting. According to their footnotes they said that they could not qualify for hedge accounting under IAS 39, therefore they reported as held for trading. In summary the difficulty of complying with the burdensome requirements for hedge accounting in IAS 39 could be the reason that Turkish companies and banks do not utilize hedge accounting. International Accounting Standards Board (IASB) should improve the hedge accounting part of the IAS 39. IASB should clearly state how to deal with the requirements of hedge accounting.

\section{References}

1. Alkeback P., Hagelin N., 1999. Derivatives Usage by Non-Financial Firms in Sweden with an International Comparison, Journal of International Financial Management and Accounting, Vol.10, Issue 2

2. Aysan M.A., 2008. National Adoption of International Financial Reporting Standard: The Turkish Case, $12^{\text {th }}$ World Congress of Accounting Historians, July 20-24, Istanbul, Turkey.

3. Bartram Söhnke M., Brown G.W., Fehle F.R., 2006. International Evidence on Financial Derivatives Usage, Working Paper

4. Bartram Söhnke M., Brown G.W., Conrad J., 2009. The Effects of Derivatives on Firm Risk and Value, Working Paper, available online at http://mpra.ub.uni-muenchen.de/9831

5. Berkram H., Bradbury M.E., Magan S., 1997. An International Comparison of Derivatives Use, Financial Management, Vol. 26 Issue 4, Winter

6. Bhamornsiri S., Schroeder R.G., 2004. The Disclosure of Information on Derivatives under SFAS No.133: Evidence from the Dow 30, Managerial Auditing Journal, Vol.19, No.5

7. Bodnar G.M., Hayt G.S., Marston R.C., 1998. 1998 Wharton Survey of Financial Risk Management by US Non-Financial Firms, Financial Management, Vol. 27 Issue 4

8. Capital Markets Board, Communiqué on Accounting Standards, Serial XI, No. 25, 2003.

9. Capital Markets Board, Communiqué" on "Essentials on Financial Reporting to the Capital Markets", Serial XI, No. 29, 2008.

10. Clark J., 2009. Comparative Analysis of Financial Risk Management Practice and Hedge Accounting Strategies Under IFRS in Europe, European Accounting Association $32^{\text {nd }}$ Annual Congress, Tampere, Finland.

11. De Ceuster M.J.K., Laveren E., Lodewyckx J., 2000. A Survey into the Use of Derivatives by Large Non-Financial Firms Operating in Belgium, European Financial Management, Vol.6 No.3

12. Hausin M., Hemmingsson C., Johansson J., 2008. How to Hedge Disclosures? IFRS 7 and Hedge Accounting, Master thesis within Business Administration, Handelshögskolan Vıd Göteborgs Universitet, Spring

13. Joseph N.L., 2000. The Choice of Hedging Techniques and the Characteristics of UK Industrial Firms, Journal of Multinational Financial Management, Vol.10 Issue 2, 2000.

14. Mallin C., Ow-Yong K., Reynolds M., 2001. Derivatives Usage in UK Non-Financial Listed Companies", European Journal of Finance, Vol. 7 Issue 1

15. Nan L., 2007. Impact of SFAS 133 on Speculation and Hedging, Working Paper, Carnegie Mellon University David A. Tepper School of Business, September

16. Selvi Y., Türel A., Yilmaz M.K., Kurun E., 2007. Türev Ürün Sözleşmelerinin Reel Sektör Şirketleri Tarafından Kullanımı ve Riskten Korunma Muhasebesi Açısından Değerlendirilmesi: İMKB-100 Şirketleri Üzerine Bir İnceleme, The World of Accounting Science, Vol. 9 Issue 4, December

17. Türel A., 2008. Riskten Korunma Muhasebesi ve Finansal Tablolarda Raporlanmas1, PhD Dissertation, June 
18. Zhang H., 2009. Effect of Derivative Accounting Rules on Corporate Risk-Management Behaviour, Journal of Accounting and Economics, Vol. 47 Issue 3

19. International Financial Reporting Standards: A Practical Guide, Third Edition, Deloitte Touche Tohmatsu, December 2002.

20. http://www.iasplus.com/standard/ias32.htm, July 07, 2006.

21. http://www.kpmg.lu/Download/IFRS\%20Briefing/IFRSBriefing\%20Sheet\%20\%20Issue\%2034.september2005.pdf, July 20, 2006. 